\title{
Antitubercular drugs induced hepatic oxidative stress and ultrastructural changes in rats
}

\author{
SD Saraswathy ${ }^{* *}$, CS Shyamala Devi \\ From First International Science Symposium on HIV and Infectious Diseases (HIV SCIENCE 2012) \\ Chennai, India. 20-22 January 2012
}

\section{Background}

As the adverse side effect hepatotoxicity, constitutes an essential part of antituberculosis chemotherapy, the present study was designed to investigate the pathogenesis of antituberculosis (anti-TB) drugs induced hepatic effects in rats with the first-line treatment regimen of isoniazid, rifampicin and pyrazinamide.

\section{Methods}

The rats were divided into three groups $(n=6$ per group), group I served as a control, group II received orally combination of isoniazid ( $15 \mathrm{mg} / \mathrm{kg}$ body weight), rifampicin $(20 \mathrm{mg} / \mathrm{kg}$ body weight) and pyrazinamide (35mg/kg body weight) daily for 45 days and group III received simultaneously Silymarin $(50 \mathrm{mg} / \mathrm{kg}$ body weight) and combination of anti-TB drugs at the above mentioned dosages for 45 days. After the experimental period, the levels of malondialdehyde (MDA, oxidative stress marker) and lipid profile was evaluated in serum. The data were analyzed by Duncan's multiple range tests. The pathological and morphological changes were examined histologically and electron microscopically.

\section{Results}

The rats administered anti-TB drugs alone, showed a significantly increase in serum MDA levels and lipid profile $(\mathrm{p}<0.001)$. Histopathological features of group II rats showed inflammatory cell infiltration and spotty necrosis. The electron micrograph results indicated kupffer cell hyperplasia, swollen mitochondria and loss of cell architecture. Co-administration of Silymarin significantly decreased anti-TB drugs-induced changes in

\footnotetext{
* Correspondence: sd.saraswathy@gmail.com

${ }^{1}$ Department of Biomedical Science, Bharathidasan University, Tiruchirappalli 620 024, India

Full list of author information is available at the end of the article
}

serum MDA levels, lipids $(\mathrm{p}<0.001)$ and retained the liver integrity.

\section{Conclusions}

The anti-TB drugs can induce hepatic oxidative stress and the level of serum MDA may be a more sensitive biomarker for monitoring drug-induced hepatotoxicity. Hepatoprotective compounds with antioxidant potential can be supplemented to prevent anti-TB drugs induced cellular oxidative stress.

\section{Author details}

'Department of Biomedical Science, Bharathidasan University, Tiruchirappalli 620 024, India. ${ }^{2}$ Department of Biochemistry, University of Madras, Chennai 600025 , India.

Published: 4 May 2012

doi:10.1186/1471-2334-12-S1-P85

Cite this article as: Saraswathy and Devi: Antitubercular drugs induced hepatic oxidative stress and ultrastructural changes in rats. BMC Infectious Diseases 2012 12(Suppl 1):P85.
Submit your next manuscript to BioMed Central and take full advantage of:

- Convenient online submission

- Thorough peer review

- No space constraints or color figure charges

- Immediate publication on acceptance

- Inclusion in PubMed, CAS, Scopus and Google Scholar

- Research which is freely available for redistribution

Submit your manuscript at www.biomedcentral.com/submit
() Biomed Central

\section{Biomed Central}

